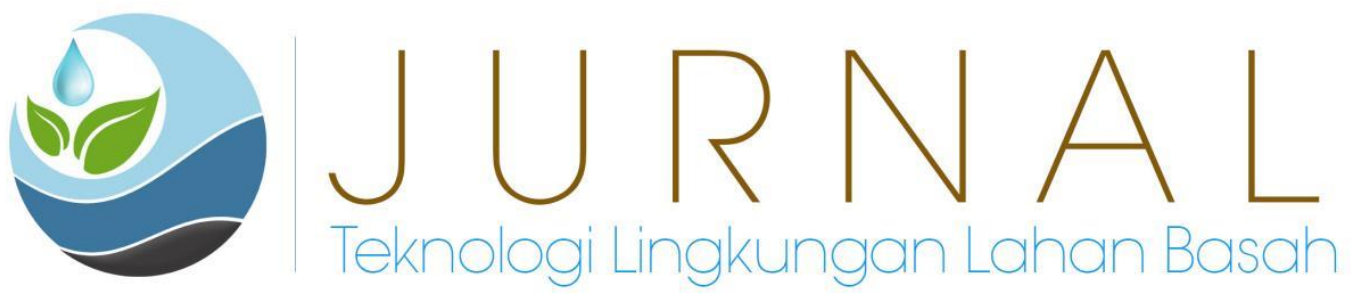

\title{
Peluang Penerapan Produksi Bersih pada Industri Rumahan Mie Ayam dan Kulit Pangsit (Studi Kasus di Kuala Dua Kabupaten Kubu Raya)
}

\author{
Shintya Murhaliza Fitri ${ }^{1}$, Nur Astinning Tiyas ${ }^{1}$, Lisa Astridni Putri ${ }^{1}$, \\ Dian Rahayu Jati ${ }^{1}$ dan Isna Apriani ${ }^{1}$ \\ ${ }^{1}$ Jurusan Teknik Lingkungan, Fakultas Teknik, Universitas Tanjungpura \\ Jl. Prof. Dr. H. Hadari Nawawi, Pontianak \\ E-mail : lisaastridni@student.untan.ac.id
}

\begin{abstract}
The application of clean production in the home industry of chicken noodles and dumpling skin in Kuala Dua, Kabupaten Kubu Raya, can reduce waste that can have a negative impact on the environment. This study aims to provide opportunities for solid waste utilization to determine the factors that affect its management and provide information to formulate steps that can be used to improve and improve solutions to the waste treatment system in accordance with the applicable procedures. The method used in this research is qualitative approach. The data obtained from the field survey are collected and then processed and analyzed from the literature journal. The results of this study indicate that the application of clean production can minimize the adverse impacts that will be caused to the environment. The benefits of clean production that have been implemented are that it can prevent and overcome environmental pollution due to solid waste that is not properly managed by the industry.
\end{abstract}

Keywords: clean production; noodle industry; waste

\begin{abstract}
Abstrak
Penerapan produksi bersih pada industri rumahan mie ayam dan kulit pangsit di Kuala Dua Kabupaten Kubu Raya dapat mengurangi limbah yang dapat berdampak buruk bagi lingkungan. Penelitian ini bertujuan memberi peluang pemanfaatan limbah padat, untuk mengetahui faktor-faktor yang mempengaruhi pengelolaannya dan memberikan informasi untuk menyusun langkah-langkah yang dapat digunakan untuk memperbaiki dan meningkatakan solusi pada sistem pengolahan limbah sesuai dengan prosedur yang berlaku. Metode yang digunakan dalam penelitian ini ialah pendekatan kualitaif. Data-data yang didapatkan dari survey lapangan dikumpulkam kemudian diolah dan dianalisis dari literatur ilmiah. Hasil dari penelitian ini menunjukkan bahwa penerapan produksi bersih dapat meminimalisir dampak buruk yang akan ditimbulkan terhadap lingkungan. Manfaat produksi bersih yang sudah diterapkan yaitu dapat mencegah dan mengatasi pencemaran lingkungan akibat limbah padat yang tidak dikelola oleh industri dengan baik.
\end{abstract}

Kata Kunci: industri rumahan mie; limbah; produksi bersih 


\section{PENDAHULUAN}

Mie basah dapat bertahan sekitar 36 jam sementara di musim hujan mie basah hanya bertahan sekitar 20-22 jam. Mie basah dapat diklasifikasikan sebagai produk dengan kadar air lebih tinggi $( \pm 60 \%)$, sehingga umur simpannya tidak lama. Perkembangan industri rumahan mie ayam dan kulit pangsit yang pesat memang sangat menguntungkan, namun di sisi lain juga akan berdampak cukup negatif, karena akan menghasilkan limbah padat, cair maupun gas yang akan mengakibatkan penurunan kualitas lingkungan.

Mie ayam atau mie basah banyak diproduksi dalam skala rumah tangga atau industri kecil. Terdapat sebuah industri rumahan pengolahan mie ayam dan kulit pangsit yang terletak di Kuala Dua, Kabupaten Kubu Raya (0¹0' 18.21" S ,109²6' 2.37" E). Salah satu limbah yang dihasilkan yaitu limbah padat. Limbah padat yang dihasilkan berupa ceceran tepung bekas adonan mie dan cangkang telur. Pemotongan mie dengan alat juga menghasilkan limbah lainnya berupa ceceran mie yang terjatuh di lantai yang menyebabkan kurang efisiennya pengolahan mie tersebut, karena tidak semua adonan dan bahan dapat dimanfaatkan dengan baik. Maka diperlukan pengelolaan limbah yang tersistem dengan penerapan produksi bersih yang memiliki peluang dalam menambah nilai ekonomi. Produksi bersih merupakan strategi untuk mengurangi pencemaran lingkungan dengan cara mengurangi konsumsi sumber daya dan mengurangi limbah yang dihasilkan dalam proses produksi, dan proses produksi terus dilakukan melalui pengelolaan limbah.

Adapun tujuan dari dilakukannya penelitian ini adalah menciptakan konsep penerapan produksi bersih pada industri rumahan mie ayam dan kulit pangsit sekaligus mengetahui efisiensi penerapan produksi bersih pada industri mie ayam dan kulit pangsit dalam mengurangi pencemaran lingkungan serta memberikan informasi dalam rangka menyusun langkah-langkah yang dapat dijadikan solusi perbaikan dan pembenahan pada sistem pengolahan limbah padat sesuai dengan prosedur yang berlaku.

\section{METODE PENELITIAN}

Lokasi Penelitian ini dilakukan di industri rumahan pengolahan mie ayam dan kulit pangsit yang berlokasi di Kuala Dua, Kabupaten Kubu Raya, Kalimantan Barat. Penelitian ini menggunakan metode deskriptif, dengan tujuan untuk menganalisis kegiatan di lapangan yang menekankan pada hasil pengumpulan data dari informan yang telah ditentukan sehingga memperoleh temuan penelitian. Subjek penelitian difokuskan pada Industri Rumahan Mie Ayam dan Kulit Pangsit. Tahapan penelitian ini terdiri dari memilih lokasi penelitian, mengurus perizinan, pengumpulan data, analisis data, dan terakhir pemilihan konsep produksi bersih.

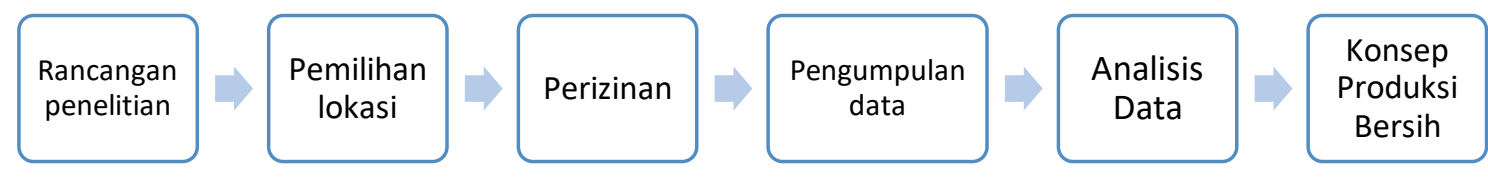

Gambar 1. Tahapan Penelitian 


\section{HASIL DAN PEMBAHASAN}

\section{Proses Produksi Mie Ayam dan Kulit Pangsit}

Proses produksi mie ayam dan kulit pangsit menyesuaikan dengan pemasaran yang mempunyai sistem pemesanan terlebih dahulu sehingga proses produksi dalam sehari mengikuti banyaknya pesananan. Produk mie ayam dan kulit pangsit ini tidak tahan disimpan lama karena tidak menggunakan bahan pengawet.

Proses produksi dimulai dari pencampuran bahan dan proses pengadukan, proses pembentukan lembaran adonan, pemotongan lembaran adonan, dan pengemasan akan menghasilkan buangan yang berdampak bagi masyarakat dan lingkungan jika tidak dilakukan pengolahan. Limbah yang dihasilkan berupa ceceran bekas adonan dan cangkang telur yang dapat diminimalisir menggunakan pendekatan produksi bersih, dengan mempertimbangkan alternatif terbaik dalam aspek teknis, ekonomi, dan ramah lingkungan. Proses produksi yang bersih akan meningkatkan efisiensi penggunaan bahan baku dan energi, mencegah atau mengganti penggunaan zat berbahaya dan beracun, mengurangi pembuangan dan kadar zat beracun pada proses industri mie ayam dan kulit pangsit, dan mengurangi pembuangan limbah ke lingkungan.

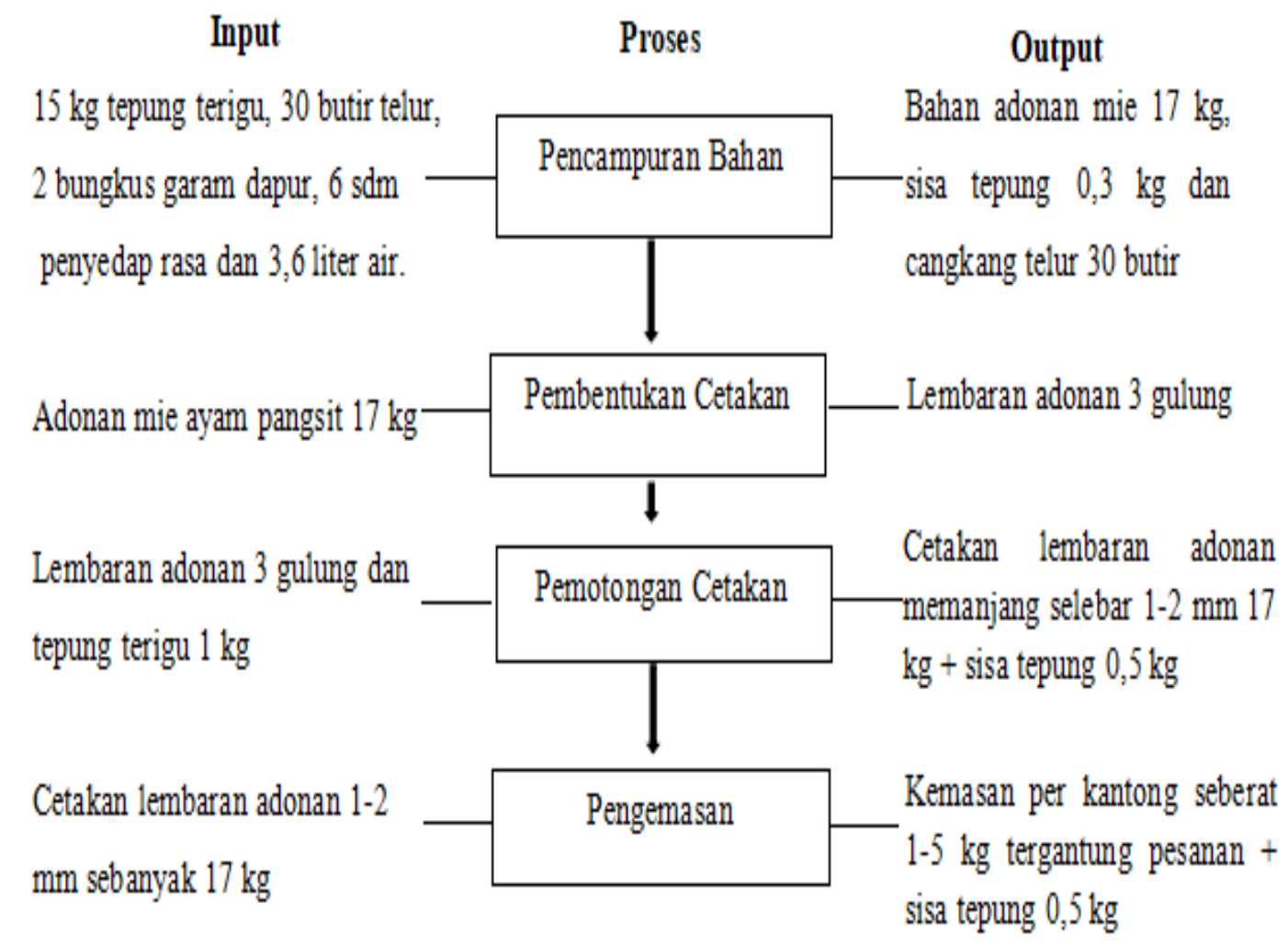

Gambar 2. Diagram Alir Proses Produksi Mie Ayam dan Kulit Pangsit 


\section{a. Persiapan Bahan Baku}

Bahan baku yang digunakan tepung terigu, telur dan air. Proses produksi mie ayam dan kulit pangsit dalam sehari menggunakan $15 \mathrm{~kg}$ tepung terigu, 30 telur dan 3,6 liter air.
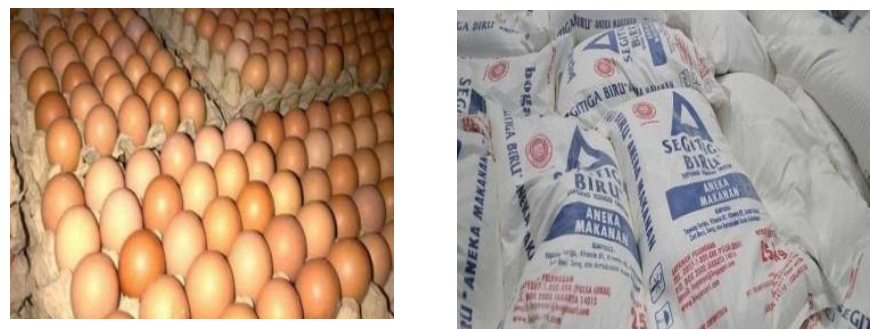

Gambar 3. Bahan Baku Produksi

\section{b. Proses Produksi}

Berikut ini adalah proses produksi dalam pembuatan mie ayam dan kulit pangsit:

1. Proses Pencampuran Bahan

Pencampuran bahan adalah tahap paling awal dalam proses pembuatan mie ayam dan kulit pangsit. Tujuan dari pencampuran bahan ini adalah agar bahan bahan tercampur merata. Proses ini dilakukan secara otomatis menggunakan alat dengan bantuan 1 orang karyawan. Adonan mie ayam dan kulit pangsit terdiri dari tepung terigu $15 \mathrm{~kg}$, air secukupnya, 30 telur, garam dapur $2 \mathrm{bks}$, gula pasir $5 \mathrm{sdm}$, penyedap rasa $6 \mathrm{sdm}$. Komposisi adonanan dimasukkan ke mesin pengaduk. Adonan diaduk dengan mesin pengaduk secara otomatis selama kurang lebih 20 menit.
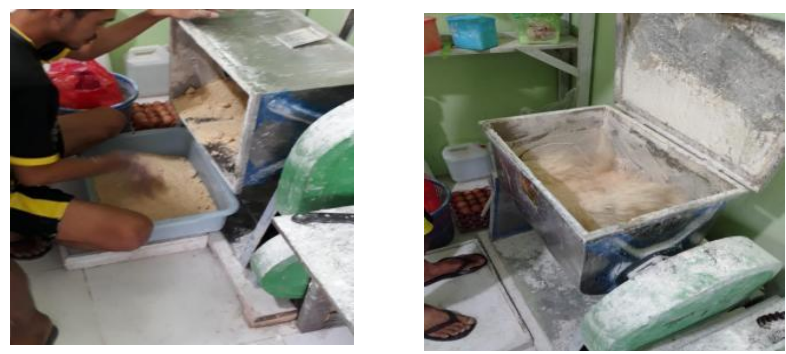

Gambar 4. Proses pencampuran bahan dan pengadukan

\section{Pembentukan Potongan Adonan (Roll Press)}

Adonan mie ayam dan kulit pangsit yang telah tercampur kemudian dimasukkan ke mesin roll press. Pressing merupakan proses pembentukan potongan adonan dengan ketebalan tertentu.
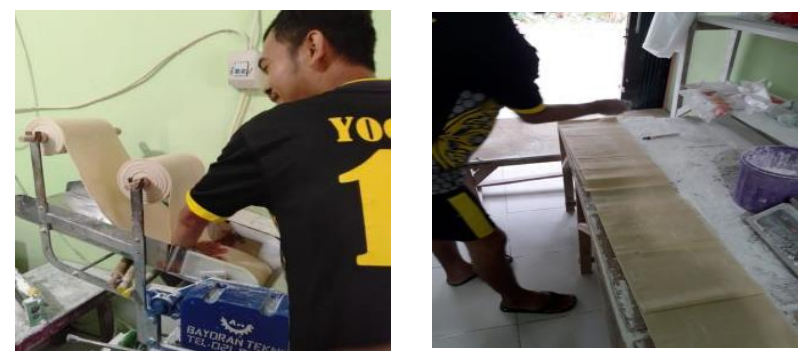

Gambar 5. Proses Pembentukan Potongan Adonan 
3. Pencetakan Potongan Adonan

Gunakan alat roll pemotong mie untuk mencetak adonan. Potong lembaran adonan memanjang menjadi 1-2 $\mathrm{mm}$, lalu potong dengan panjang tertentu sehingga akan menghasilkan berat standar dalam keadaan kering.

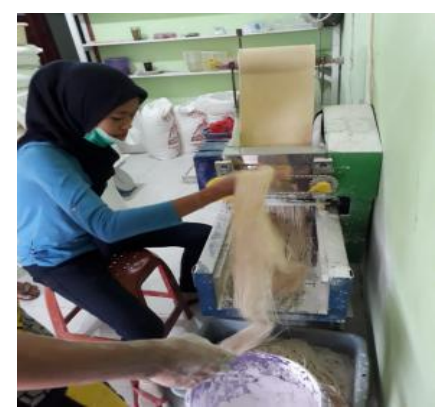

Gambar 5. Pencetakan Potongan Adonan

4. Proses Pengemasan

Mie ayam dan kulit pangsit kemudian disortir untuk dipilah dan dikemas, mie ayam dan kulit pangsit dimasukkan ke dalam plastik $1 \mathrm{~kg}$ secara manual kemudian ditutup dan disimpan di gudang penyimpanan. Proses ini dilakukan oleh 1 orang karyawan. Proses pengemasan ini tidak dilakukan pencampuran bumbu, karena bumbu perasa akan diberikan tergantung pesanan konsumen.

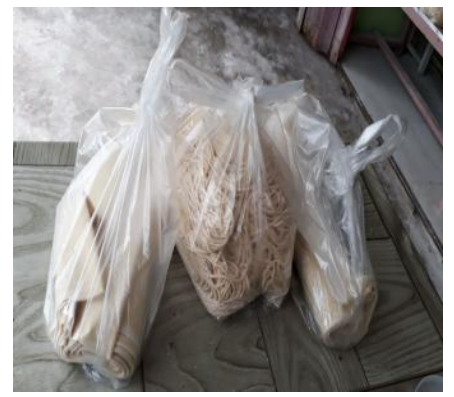

Gambar 6. Proses Pengemasan Mie Ayam dan Kulit Pangsit

\section{PELUANG PRODUKSI BERSIH}

Industri rumahan mie ayam dan kulit pangsit di Kuala Dua, Kabupaten Kubu Raya, menghasilkan limbah padat berupa cangkang telur dan sisa tepung terigu. Produksi bersih yang ditawarkan kepada industri rumahan ini adalah perbaikan mutu olahan mie ayam dan kulit pangsit, pemanfaatan cangkang telur sebagai pupuk organik dan pemanfaatan sisa tepung terigu sebagai pakan ternak.

\section{A. Perbaikan mutu olahan mie ayam dan kulit pangsit}

Air merupakan komponen yang penting dalam indutri pengolahan mie ayam dan kulit pangsit. Masih banyak industri rumahan yang menggunakan air yang umumnya bersumber dari air PDAM dan air hujan, namun air tersebut digunakan tanpa pengolahan terlebih dahulu. Pada industri rumahan pengolahan mie ayam dan kulit pangsit di daerah Kuala Dua, Kabupaten Kubu Raya menggunakan sumber air hujan 
dan tanpa pengolahan. Hal ini dapat menyebabkan adanya kontaminan yang masuk dalam pengolahan mie ayam dan kulit pangsit. Maka dari itu diperlukan pengolahan terlebih dahulu terhadap air yang akan digunakan dengan cara merebus air hujan hingga mencapai $100^{\circ} \mathrm{C}$ untuk menghilangkan kontaminan di dalamnya.

\section{B. Pemanfaatan cangkang telur sebagai pupuk organik}

Kandungan kalsium pada cangkang telur uang cukup besar dapat dimanfaatkan sebagai sumber nutrisi bagi tanaman. Kalsium merupakan suatu zat yang berperan penting dalam pembentukan dinding sel pada tanaman.

Adapun alat-alat yang gunakan dalam mengolah cangkang telur sebagai pupuk organik yaitu: penumbuk, saringan, baskom, dan sendok karung. Adapun bahan yang digunakan hanya cangkang telur limbah sisa pengolahan mie ayam di Industri Rumahan Mie Ayam dan Kulit Pangsit, Kuala Dua. Berikut ini cara pembuatan cangkang telur sebagai pupuk organik:

1. Cangkang telur dicuci bersih dan dikeringkan

2. Cangkang telur yang kering ditumbuk

3. Cangkang telur kering yang halus disaring sehingga menghasilkan serbuk cangkang telur

4. Untuk penggunakaan sebagai pupuk, serbuk cangkang telur ditaburi diatas tanah sekitar batang tanaman

\section{Pemanfaatan sisa tepung terigu hasil produksi mie ayam dan kulit pangsit sebagai pakan ternak.}

Limbah tepung terigu dihasilkan dari sisa proses pembuatan mie ayam dan kulit pangsit. Penggunakan tepung terigu ditujukan untuk memisahkan antara helaian mie satu dengan yang lainnya agar tidak melekat. Dari proses tersebut tepung terigu sisa yang dihasilkan cukup banyak dan berserakan serta berceceran di meja pengolahan hingga lantai. Adapun alat yang digunakan untuk mengolah sisa tepung terigu sebagai pakan ternak adalah baskom atau ember dan pengaduk. Adapun bahan yang digunakan untuk mengolah sisa tepung terigu sebagai pakan ternak yaitu:

a. Tepung terigu limbah sisa pengolahan mie ayam dan kulit pangsit

b. Dedak (sebagai tambahan nutrisi dalam pakan)

c. Air

Adapun cara pembuatan mengolah sisa tepung terigu sebagai pakan ternak sebagai berikut:

1. Siapkan wadah ember atau baskom

2. Limbah tepung terigu dan dedak dimasukkan ke dalam wadah, diaduk rata.

3. Kemudian campurkan air agar pakan menjadi adonan dan dapat merekat.

\section{KESIMPULAN}

1. Timbulan limbah yang dihasilkan pada proses produksi mie ayam dan kulit pangsit adalah limbah padat yang berupa cangkang kulit telur dan sisa tepung terigu dari bekas adonan. 
2. Beberapa peluang penerapan produksi bersih yang dapat dilakukan pada industri rumahan mie ayam dan kulit pangsit di Kuala Dua, Kabupaten Kubu Raya yaitu: (a) Perbaikan mutu pada olahan mie ayam dan kulit pangsit ini dapat menyebabkan adanya agar kontaminan yang masuk dalam pengolahan mie ayam dan kulit pangsit dapat diminimalisir. Maka dari itu diperlukan pengolahan terlebih dahulu terhadap air yang akan digunakan dengan cara merebus air hujan hingga mencapai $100^{\circ} \mathrm{C}$ untuk menghilangkan kontaminan di dalamnya. (b) Pemanfaatan cangkang telur sebagai pupuk organik, kandungan kalsium pada cangkang telur uang cukup besar dapat dimanfaatkan sebagai sumber nutrisi bagi tanaman. (c) Pemanfaatan sisa tepung terigu hasil produksi mie ayam dan kulit pangsit sebagai pakan ternak.

\section{UCAPAN TERIMA KASIH}

Kami mengucapkan terima kasih kepada semua pihak yang telah membantu dan terlibat dalam penelitian ini, antara lain kepada dosen pengampu mata kuliah Teknologi Bersih dan Minimasi Limbah sekaligus dosen pembimbing Ibu Isna Apriani, S.T., M.Si. dan Ibu Dian Rahayu Jati, S.T., M.Si, yang mendukung jalannya penelitian serta kepada pemilik dan karyawan industri rumahan mie ayam dan kulit pangsit di Kuala Dua, Kabupaten Kubu Raya, Kalimantan Barat yang telah memberikan izin untuk melakukan penelitian di industri ini sehingga dapat terlaksana dengan baik.

\section{DAFTAR PUSTAKA}

Aminah, Siti. Wulandari, M. 2016. Calcium Content and Flour Yield of Poultry Eggshell With Acetic Acid Extraction. Prosiding Seminar. The $4^{\text {th }}$ University Research Coloquium 2016. ISSN 2407-9189.

Asterina. 2008. Identifikasi dan Penentuan Kadar Boraks pada Mie Basah yang Beredar Dibeberapa Pasar di Kota Padang. Majalah Kedokteran Andalas, 174-179.

Cahyadi, W. 2006. Kajian dan Analisis Bahan Tambahan Makanan. Bumi Aksara : Jakarta.

Ernawati, E E. Noviyanti, A R. Yuliyati, Y B. 2019. Potensi Cangkang Telur Sebagai Pupuk Pada Tanaman Cabai Di Desa Sayang Kabupaten Jatinangor. Jurnal Pengabdian Kepada Masyarakat. 4 (5) : 123-125.

Gisslen. 2013. Essentials of Professional Cooking. John Wiley \&. Sons, Inc : New Jersey.

Gunawan, Adi W. (2006). Genius Learning Strategy. PT. Gramedia : Jakarta.

Juniawati. 2003. Optimasi Proses Pengolahan Mi Jagung Instan Berdasarkan Preferensi Konsumen. (Skripsi). IPB : Bogor.

Kementerian Lingkungan Hidup. 2003. Karakteristik dan Cara Pengelolaan Air Llimbah serta Dampaknya Terhadap Lingkungan. KLH : Jakarta.

Kementerian Lingkungan Hidup. 2006. Pedoman Pemanfaatan \& Pengolahan Limbah Tapioka. KLH : Jakarta. 
Koswara, S. 2009. Teknologi Pengolahan Mie. Seri Teknologi Pangan Populer. EBookPangan.com

Mahreni. Endang Sulistyowati. Saeful Sampe. Willyam Chandra. 2012. Pembuatan Hidroksi Apatit Dari Kulit Telur. Di dalam: Proseding Seminar Nasional Teknik Kimia : Yogyakarta.

Nugrahani, M D. 2005. Perubahan Karakteristik Dan Kualitas Protein Pada Mie Basah Matang Yang Mengandung Formaldehid Dan Boraks. IPB : Bogor.

Nuraida, Lilis. 2008. Keamanan Pangan Industri Usaha Kecil Dan Menengah (UKM) Dan Industri Rumah Tangga (IRT) Pangan. SEAFAST Center \& IPB : Bogor.

Payu, M. Abidjulu, J. Gayatriningtyas, C. 2014. Analisis Boraks pada Mie Basah yang dijual di Kota Manado. Pharmacon, 73-76.

Purwaningtyas, S. A dkk. 2017. Pemanfaatan Limbah Produksi Mie Sebagai Alternatif Pakan Ternak. Universitas Negeri Semarang

Safitri, N.M dkk. 2020. Pembuatan Formulasi Pakan Apung Ikan Berbahan Baku Lokal. Jurnal Perikanan Pantara Vol.3, No.1. Gresik

Surasen, C. 2002. Removal of Cadmium in Synthetic Wastewater by Egg Shell Filter. Thesis Faculty of Graduate Studies. Kasetsart University : Bangkok 